\title{
INTERRELATION OF ALKALOID CONTENT AND STAGE OF DEVELOPMENT OF 1- AND 2-YEAR-OLD ATROPA BELLADONNA L.
}

\author{
G. ELZENGA and J. W. DE BRUYN \\ Institute of Horticultural Plant Breeding, Wageningen
}

Received 27 Aug. 1956

\section{INTRODUCTION}

Successful selection is primarily dependent on a thorough knowledge of the characters of the crop under selection. When selecting $A$. belladonna for high alkaloid content we established that in one and the same plant this content was far from constant during the course of growth. Hence the question arose in which stage the plants contain the highest alkaloid content.

BREWER and HiNER (1) found the highest content in A. belladonna during flowering. The British Pharmacopoeia (3) probably agrees with this, since it requires that the plant shall be harvested during flowering. On the other hand CARR (2) did not find any significant differences in the alkaloid content at the different stages of development, except that the concentration decreases rapidly when the leaves are dying. EvaNs and ParTRIDGe (6) encountered the highest concentration in 1-year-old $A$. belladonna during flowering. The concentration falls markedly during fruit setting. At first the alkaloid content of 2-year $A$. belladonna is high, but later it decreases rapidly until flowering begins, remains steady during flowering and after that decreases further.

Rowson (8), in his paper on research on $A$. belladonna, emphasizes the importance of collecting actively growing aerial parts to obtain a maximum content of 1 -hyoscyamine.

\section{METHOD OF INVESTIGATION}

In order to reduce any possible influence of soil differences on the alkaloid content, each trial was duplicated. Each block consisted of 25 rows of 10 plants each. The plant material used had not been selected. The trials were laid out in a sandy soil, which was yearly manured with $41.5 \mathrm{~kg}$. N, $43.7 \mathrm{~kg} . \mathrm{P}_{2} \mathrm{O}_{5}$ and $84.2 \mathrm{~kg}$. $\mathrm{K}_{2} \mathrm{O}$ per acre, and received in addition 24.3 ton stable manure every other year.

The leaves, stems or herb (the whole aerial part of the plant) were harvested twice a week, always at about 10 a.m. Each time 1 row of each block was harvested, dividing the row into 3 groups of plants ( 2 groups of 3 and 1 group of 4 plants). These groups were harvested separately. After the material had been weighed, cut up fine and mixed, a sample was taken and dried at $55-60^{\circ} \mathrm{C}$. Then the total alkaloid content in the air-dry material was determined by the method of DIJKSTRA (4). The means of the 6 analyses per harvesting date were plotted in graphs. We shall discuss our findings from these graphs. 


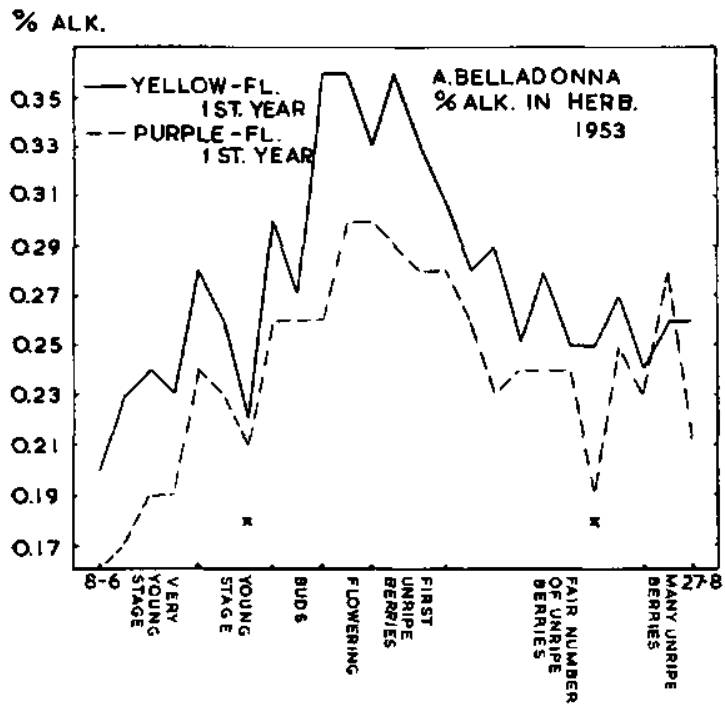

FIG. 1.

COURSE OF THE ALKALOID CONTENT OF I-YEAR-OLD BELLLADONNA HERB (1953)

\section{EXPERIMENTAL RESULTS}

The course of the alkaloid content in 1-year-old A. belladonna during growth

On May 22, 1953, two fields were planted with 1-year-old yellow-flowered and 1-year-old purple-flowered plants of $A$. belladonna, the two kinds well apart from each other. Harvesting was started in a very young stage on June 8 . The last harvest was carried out on August 27 when the plants already bore many berries.

Figure 1 clearly shows that the total alkaloid content increases during growth until flowering begins and remains steady until the first berries appear. After that it drops

Fig. 2.

Course OF THE ALKaloid CONTENT AND YIELD OF 1YEAR-OLD BELLADONNA HERB (1955)

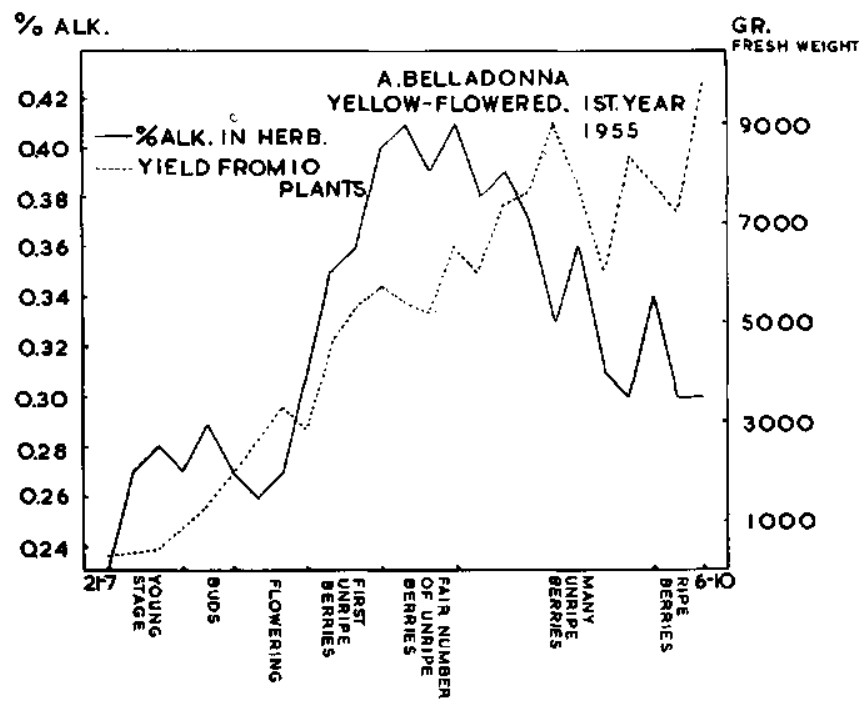


again. Although the overall level of alkaloid is lower in purple-flowered plants, both varieties show parallel changes in alkaloid content during growth. The marked decreases (x) in alkaloid content which occasionally occur cannot be explained from the weather conditions (temperature, cloudiness, precipitation), which were equable during those periods.

The course of the alkaloid content in 1-year-old yellow-flowered A. belladonna was again determined in 1955. Owing to the unfavourable spring weather harvesting could not be started until July 21 , i.e. 6 weeks later than in 1953. As is shown in Fig. 2, the changes in 1955 are very much the same as in 1953; only the maximum is a little higher and is reached somewhat later, when the plant has already produced several unripe berries.

The weight of the aerial parts increases regularly, even when the plants bear ripe berries. Too small a number of replicates may account for the irregular course of the weight curve.

Figs. 1 and 2 demonstrate that the maximum alkaloid content can be shifted to some extent.

From the experiences of Evans and PARTRIDGe, Brewer and HinER, and from data which we collected in 1953, we may conclude, however, that the maximum alkaloid content in 1-year-old $A$. belladonna is generally reached during flowering and remains steady during the first fruit setting. But afterwards there is a decrease.

The course of the alkaloid content in the leaf is entirely different from that in the stem (Fig. 3). The alkaloid content of the stem, as compared with that of the leaf, is very high in the first growing stages. As in the leaf it reaches a maximum during flowering, but as the plant grows older it falls to the level of the alkaloid content in the leaf. Also the content in the stem of the purple-flowered variety is at first higher than that of the leaf. The level of the concentration in the stem is appreciably lower than that of the yellow-flowered variety.

As the weight ratio leaf/stem in young A. belladonna is approximately $3: 1$, the

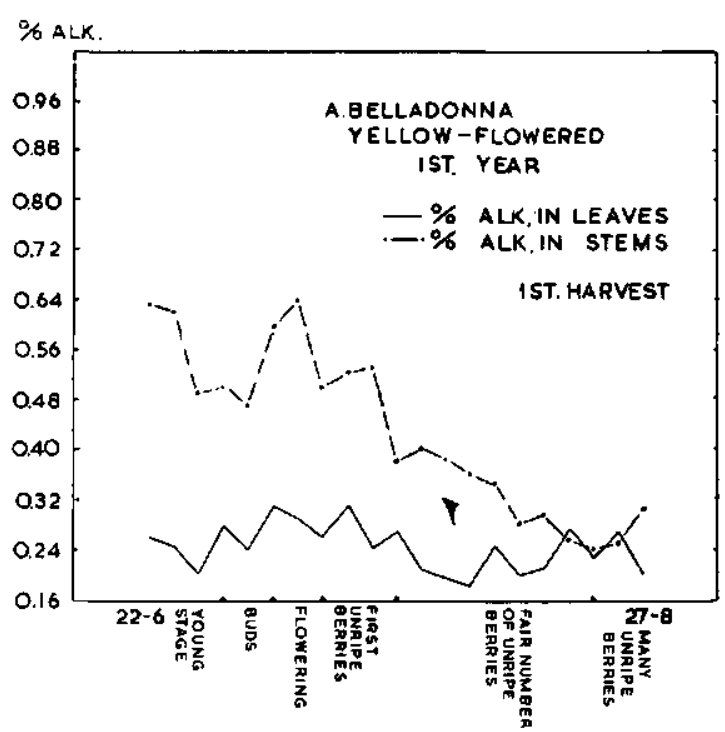

FIG. 3.

COURSE of THE aLKaloId CONTENT OF LEAVES AND STEMS OF 1-YEAR-OLD ATROPA BELLADONNA 
alkaloid of the young herb is mainly determined by the leaf. As the plant grows older this ratio more and more approaches the value $1: 1$.

The course of the alkaloid content in 2-year-old A. belladonna during growth

Since $A$. belladonna is a perennial it can be harvested for a number of consecutive years. Now it might be asked whether the course of the alkaloid content in the 2-yearold plants runs parallel to that in the 1-year plants, and whether roughly the same overall level is reached.

The course of the alkaloid content in 2-year old yellow-flowered $A$. belladonna was studied in 1953 and in 1955. As stated above, the same procedure was followed as for 1-year-old $A$. belladonna. Contrary to observations by CARR we found that the alkaloid content in the leaf clearly shows a minimum when the plant begins to flower, and a maximum when the plant bears a number of green berries (Fig. 4). The level of the alkaloid content in the leaf of 2-year-old plants is higher than in 1-year plants. The same is true of the level in the stem. One-year plants were high in alkaloids in the young stage of the shoots, but this was even more markedly the case with 2-year plants. Also with 2-year plants the content in the stem falls with the age of the shoots to the level of the concentration in the leaf. This level is reached when the plants bear ripe berries.

If leaf and stem are not harvested separately the course of the alkaloid content is as shown in Fig. 5. The course of the content of the herb in the bud stage is largely determined by the quantity in the stem at that stage (Fig. 4). A low level is reached when the plant begins to flower, after which the content increases again to a maximum which is reached when the plant bears a good many green berries. At that stage the content of the leaf and that of the stem are about equally high. After that the content drops steadily until the berries ripen off.

Fig. 5 confirms the findings of Evans and PARTrIDge that the content in the aerial part of 2-year-old plants is at first very high. Later, however, the content takes

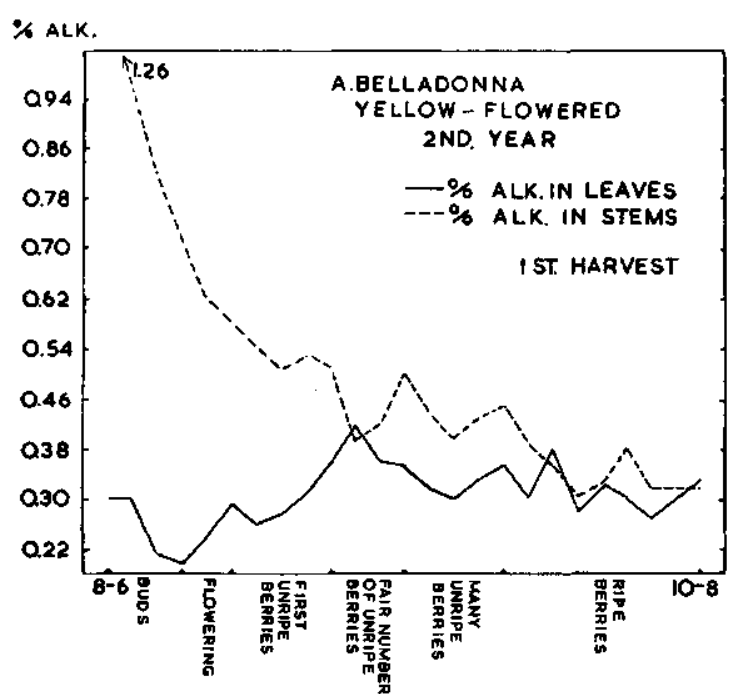

FIG. 4.

COURSE OF ALKALOID CONTENT OF LEAVES AND STEMS OF 2-YEAR-OLD ATROPA BELLADONNA 


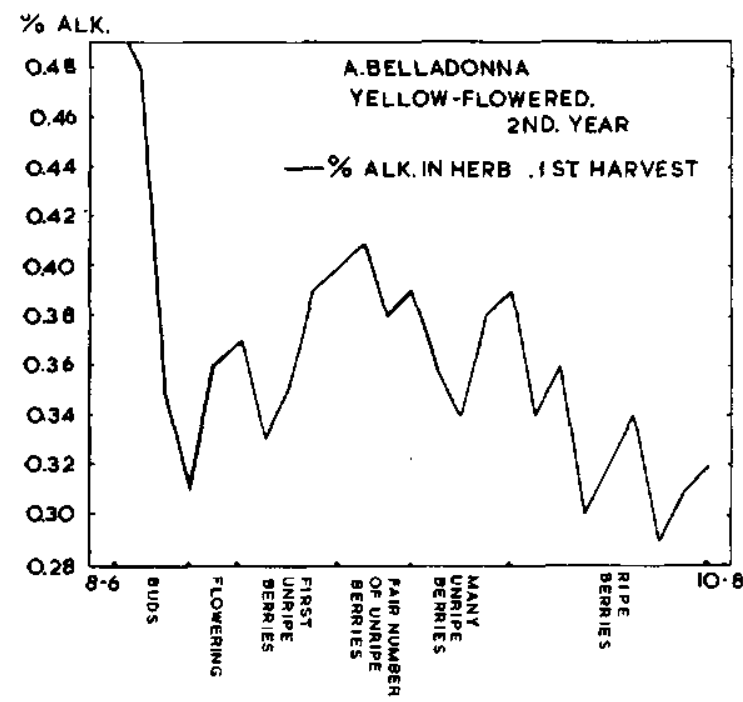

FIG. 5.

COURSE OF THE ALKALOID CONTENT OF 2-YEAR-OLD BELLADONNA HERB (1ST HARVEST, 1953)

a different course from that described by the above-mentioned workers (see Introduction).

\section{The second harvest}

Two-year-old $A$. belladonna can be harvested twice in one season if the first harvest is carried out in time, i.e. shortly after flowering.

Let us now consider the course of the alkaloid content of the plants that have resumed growth. The conditions of light and temperature are now different from those prevailing at the first growth.

The first series of harvests was carried out from the end of May to early in August,

Fig. 6.

COURSE OF THE ALKALOID CONTENT OF 2-YEAR-OLD BELLADONNA HERB (2ND HARVEST, 1953)

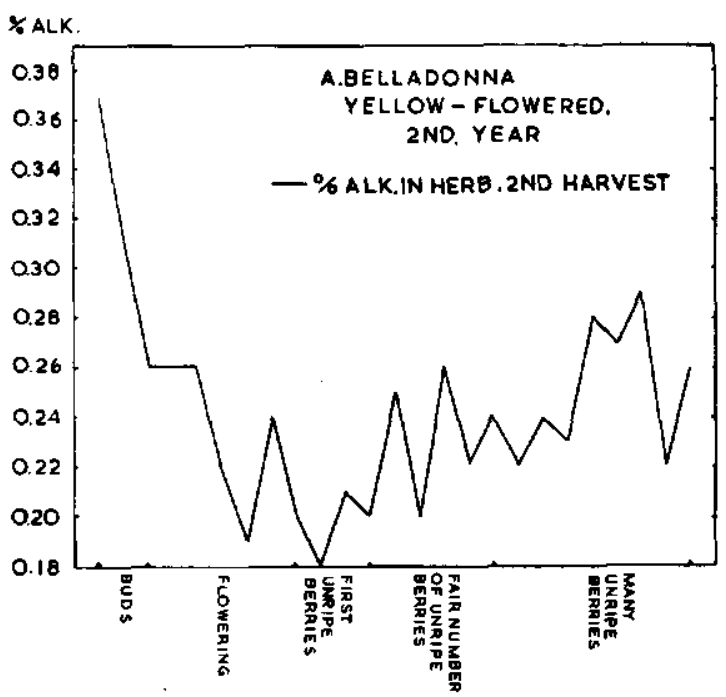


while the whole field was harvested again on September 8 , but now at one time. Due to the difference in time required by the plants to resume growth between the first and the second harvest, all developmental stages were present on September 8, except the stage in which the plant already bears ripe berries. So analyses for alkaloids in plants in that stage could not be carried out. The rows that were harvested first already bore many unripe berries, while those that were harvested last had only just come into bud.

Again we found a relatively high alkaloid content in the young stage, and this was again mainly due to the stem (Fig. 6). The subsequent changes in alkaloid content during the resumed growth are practically the same as those in shoots of the first harvest, except that the maximum is reached at a later stage, namely when the plants already bear many berries. This is mainly due to the leaves, as the content in the leaves also increases steadily until that stage is reached. As the plants grow older the content in the stem steadily decreases to the level in the leaves. Plants from the second harvest were lower in alkaloids than those from the first harvest.

\section{DISCUSSION}

If the extent to which a certain character of a plant manifests itself at a given moment depends not only on genetical factors but also on the environment and the stage of development reached by the plant at that moment, selection for the character in question becomes extremely difficult. This is often the case with plants, e.g. herbs, that are important for their content of some valuable substance.

For a number of years we have been selecting $A$. belladonna for high total alkaloids in the aerial parts. SIEvers (9) is of the opinion that the alkaloid content of $A$. belladonna is determined genetically, and STEINEGGER (10) produced evidence that this is correct for Datura stramonium, a plant that contains the same alkaloids as $A$. belladonna. ROMEIKE (7) claims that the alkaloid content is primarily determined by genetical factors and that the environment has only a slight effect.

An alkaloid content of $0.3 \%$ in the dry matter of the herb of $A$. belladonna is normal, while a content of $0.6 \%$ is high. The relative difference is $100 \%$, whereas the absolute difference is $0.3 \%$. As the selector is only concerned with such small absolute differences, it is of the utmost importance to him to know the extent to which the content, at a given moment, is determined by the genotype, the environment and the stage of development of the plant.

Like ROMEIKE we are of opinion that the environmental factors have only a slight effect, provided that there are no extreme differences and perhaps with the exception of trace elements. We will come back to this in a following publication dealing with the influence of temperature on growth and alkaloid content of A. belladonna (5).

We found that the interrelation of stage of development and alkaloid content is more important than the influence of the environment. It appeared that the relative differences in the alkaloid content of a plant from the same sowing could amount to over $100 \%$, while in the stem differences up to about $250 \%$ may occur.

When the plants are harvested at frequent intervals it becomes apparent that the course of the content is more or less systematic. It is characterised by abrupt decreases and increases, which cannot be explained from the state of the weather. They may be related to the growth rhythm of the root and the aerial part, but this would have to 
$\%$ ALK.

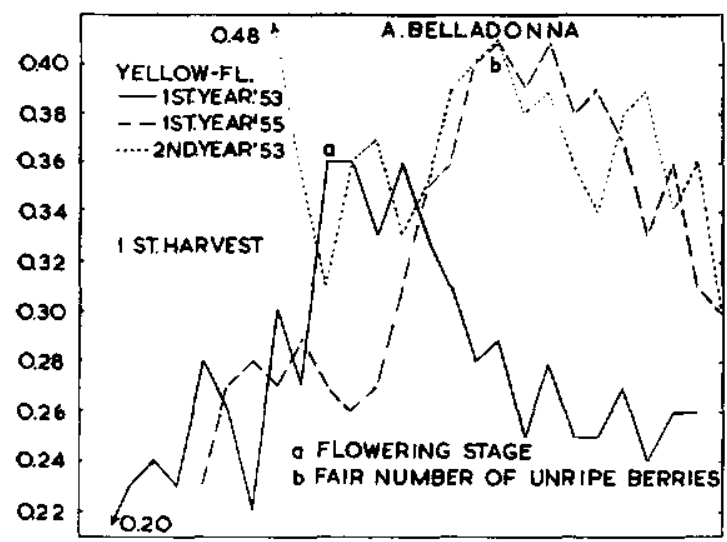

Fig. 7.

COURSE OF THE ALKALOID CONTENT OF 1- AND 2-YEAR-OLD BELLADONNA HERB (1953 AND 1955)

be investigated further. These abrupt decreases and increases do not occur in the experiments carried out by Evans and PARTRIDGe, probably because their harvest intervals were still too great. The selector can take advantage of this systematic course of the alkaloid content by carrying out all analyses at the same stage of development.

The stage at which the maximum occurs may shift to a slight extent (see Fig. 7, which is a combination of Figs. 1,2 and 5). This shift might be due to the cold spring of 1955 when growth was much slower than in 1953.

The question put in the introduction might be answered by saying that for purposes of selection or when studying the influence of environmental factors 1-year-old $\mathrm{A}$. belladonna can be best judged when the plant flowers and/or bears the first unripe berries, whereas 2-year-old A. belladonna should be judged when the plant already bears a fair number of berries. At this time it is possible to obtain information about the maximum alkaloid content.

\section{SUMMARY}

A study was made of the course of the alkaloid content in the aerial parts of both 1- and 2-year-old $A$. belladonna during growth. This content is not steady. One-year plants reach the maximum content during or just after flowering, when the plant bears a few green berries, while 2-year plants reach the maximum content in a very young stage. During flowering, however, the content drops to a low level to reach a peak again when the plant bears a good many green berries.

When judging the plants for alkaloid content it is important to harvest all plants in the same stage of development. If they are harvested at one time it would be certain that all plants would have been influenced by the same environment for the same length of time. However, a critical comparison of the potentialities of the different plants would not have been achieved. 


\section{SAMENVATTING}

\section{Het verband tussen het alkaloidegehalte en het ontwikkelingsstadium} van 1- en 2-jarige Atropa belladonna $L$.

Voor de veredeling van $A$. belladonna op alkaloïdegehalte is het belangrijk, dat alle planten in hetzelfde ontwikkelingsstadium geoogst worden. Door de planten gelijktijdig te oogsten zou men wel de zekerheid hebben dat ze gedurende eenzelfde tijd door hetzelfde milieu beïnvloed zijn, maar dit zou een kritische vergelijking van de verschillende planten ten opzichte van het gehalte dat ze kunnen bereiken onmogelijk maken.

\section{LITERATURE CITED}

1. Brewer, W. R. and Hiner, L. D., Cultivation studies of the Solanaceous drugs. IV. Time and space in Solanaceous culture. J. Amer. pharm. Ass. Sci. Ed. 39 (1950): 639-640.

2. CARR, F. H., The effect of cultivation upon the alkaloidal content of Atropa belladonna L. Chemist and Druggist 8 (1912): 42-44.

3. The cultivation of medicinal plants. Bulletin no. 121, Min. of Agr. and Fish., London, 25 pp. (1948).

4. Dijkstra, S. P., Verbeterde uitvoering van de door Hegnauer en Flück ontworpen methode voor de snelle bepaling van het alkaloidengehalte van Solanaceeën-drogerijen. Pharm. Weekbl. 86 (1951): 129-133.

5. Elzenga, G., Smeets, L. and Bruyn, J. W. DE, Influence of the temperature on growth and alkaloid content of first-year Atropa belladonna L. Euphytica 5 (1956): 276-280.

6. Evans, W. C. and Partridge, M. W., Alkaloid biogenesis. Part II. Changes in the ontogenetic production of alkaloids in Atropa and Datura. J. Pharm. Pharmacol. 5 (1953): 772-777.

7. Romeike, A., Beiträge zur Chemischen Physiologie der mydriatisch wirkenden Solanaceen-Alkaloide. Die Pharmazie 8 (1953): 668-674; 729-747.

8. Rowson, J. W., The pharmacognosy of Atropa belladonna L. J. Pharm. Pharmacol. 2 (1950): 201216.

9. SiEvers, A. F., The possibility and value of improving the commercial belladonna crop through selection. Amer. J. Pharm. 88 (1916): 193-215.

10. Steinegger, E., Untersuchungen über die Vererbung des Alkaloidgehaltes bei Datura. Pharm. Acta Helv. 27 (1952): 311-314. 
50. Algemene Veredelingsdagen 1952. Verslag van voordrachten en discussies. Juni 1953 . . . . . . . f 1,50

51. Sneep, J. Practijkproeven met Spitskool 1949-1950 en 1950-1951. Juli 1953 ............ . . f 0,65

52. Boom, B. K. Internationaal reglement voor de naamgeving van gekweekte planten ........ f 0,75

53. Kronenberg, H. G. en F. Garretsen. Opbrengstproeven met aardbeiklonen. November 1953

0,35

54. Veredelingsdag Groentegewassen 1953. Verslag van voordrachten en discussies. December 1953 . . . . . . f $1,-$

55. Floor, J. Planten in plastic. Januarj 1954. . Uitverkoche

56. Banga, $O$. Taproot-problems in the breeding of root vegecables .............. f 0,25

57. Jensma, J. R. en A. Kraai, Practijkproeven met Rode Kool 1950-1951. Juni 1954........ $\$ 1,10$

58. Jensma, J. R. en A. Kraai. Practijkproeven mec Spruitkool 1950-1951, Juli 1954 .... f 0,85

59. Veredelingsdag Fruitgewassen 1954. Verslag van voordrachten en discussies. Augustus $1954 \ldots . .$. . . 0.95

60. Kraai, A. The use of Honey-bees and Bumble-bees in breeding work. September 1954 . . . . . 0.45

61. Jensma, J. R. en A. Kraai. Practijkproeven met Witte Kool 1952-1953. Februari 1955 . . . . . . . . f 1.35

62. Banga, 0 . en $\mathbf{J}$. W. de Bruyn. Selection of Carrots for Carotene Content. Februari 1955 ... . . . f 0.25

63. Kronenberg, H. G. en L. M. Wassenaar. Practijkproeven met aardbeirassen 1952-1954. April 1955 f 0.90

64. Keuls, $M$. and J. W. Sieben. Two statistical problems in plant selection. April 1955 ... . . . . . . $\mathbf{f} \mathbf{0 . 3 5}$

65. Banga, $O$. The Institute of Horticultural Plant Breeding. April 1955 . . . . . . . . f 0.25

66. Banga, $\mathbf{O}$. Uienveredeling met gebruikmaking van inteelt en herstel door heterosis. Juni 1955

67. Banga, 0. Carrot yield analysis. September 1955 : f 0,30

68. Banga, O., J. W. de Bruyn and L. Smeets. Selection of carrots for carotene content. II Sub-normal content at low temperature September 1955

f 0,25

69. Braak, J. P. Effect of temperature and light on June Yellows in strawberries. September $1955 \ldots$... f 0,25

70. Banga, 0 . De ontwikkeling van de rassensituatie bij groentegewassen. Okzober 1955 ....... . f 0,25

71. Bruyne, A. S. de. Tendenzen in de ontwikkeling van het Nederlandse fruitsortiment. Okcober 1955 . . . f 0,40

72. Banga, O. Praktijkproeven mer Knolselderij 1953-1954. November 1955 ............. . . . f 0,30

73. Floor, J., Proeven mec stekken onder waterverneveling. April 1956

74. Andeweg, J. $M$. en J. H. Ruyten. Praktijkproeven mer Tomaten 1954-1955. April 1956 ...... f 0,40

75. Andeweg, J. M. en A. van Steenbergen. Praktijkproeven met Stoksnijbonen 1953-1954. Mej 1956 . . f 0,35

76. Banga, $\mathbf{O}$, en J. L van Bennekom. Praktikkproeven mes Ronde Witpunt Radijs 1953-1954. Mei 1956 f 0.55

77. Smeets, L. and Hester G. Kronenberg. Runner formation on strawberry plants in autumn and winter.
Smeets, L. Runner formation on strawberry plants in autumn and winter. II. Influence of the light intensity on the photoperiodical behaviour. Juni 1956 ... f 0,30

78. Smeets, $L$. Influence of the cemperacure on runner produccion in five strawberry varieties. Juni 1956 . . . f 0,25

79. Smeets, L. and L. M. Wassenaar. Problems of heat spot in Fragaria vesca $L$. when indexing strawberry selections for viruses. Juni 1956

80. Banga, $O$, and J. $W$. de Bruyn. Selection of carrots for carotene content. III Planting distances and ripening equilibrium of the roots. Junt 1956 ......... . . 0,35

81. Banga, O. International conference on the improvement and on the standardization of vegetable varieties at Wageningen, Netherlands, on August 26 and 27, 1955 August 1956 ............... . . f 0,75

82. Floor, J. Proeven met vermeerdering van houtige gewassen. September 1956 . f 0,80

83. Gerritsen, C. J. Improvement of the cherry varieties used in the Netherlands. Oktober 1956 ... . . . f 0,35

34. Gerritsen, C.J. Research offered new possibilities for nut growing in the Netheriands: Oktober 1956. . f 0,25

85. Andeweg. J. M. The breeding of scab-resistant frame cucumbers in the Netherlands. Oktoker 1956 . . f 0,30

86. Zeilinga, A. E. An improved acetic orcein squash method for serial cytological preparations. Oktober 1956 f 0,20

87. Braak,J.P. and L.Smeets, The Phytotron of the institute of Horticultural Plant Breeding at Wageningen, the $\mathrm{Ne}$ theriands. Oktober 1956....... f 0,30

88. Banga, $O$. and L. Smeets. Some effects of the photoperiod on growth and pithiness of radish. Oktober 1956. . 0.30

89. Kho, Y. O. and J.P. Braak, Reduction in the yield and viability of carrot seed in relacion to the occurence of the plant bug Lygus campestris L. Oktober 1956 . f 0,35

90. Terpstra, $\mathbf{W}$. Some factors influencing the abscission of debladed leaf petioles. Oktober 1956 . . . . f 0,35

91. Keuls, M. en J. J. Post. Invloed van de temperacuur op de groei van asperges. Januari 1957... . . f 0.70

92. Smeets, L. Some effects of the photoperiod on the shoot growth of cherry seedlings. Febr. 1957 . . 0,30

93. Elzenga, G. and J, W. de Bruyn. Interrelation of alkaloid content and stage of development of 1- and 2-year - old - Atropa belladonna L. Febr. 1957 .... 0,30

94. Elzenga, G., L. Smeets and J. W. de Bruyn. Influence of the temperature on growth and alkaloid content of first-year Atropa belladonna L. Februari 1957 . f 0,25

95. Ferguson, J. H. A. Some applications of binomial probability paper in genetic analyses. Februari 1957.0 .35

96. Jensma, J. R. Teelt en veredeling ran bloemkool. Maart 1957............. . f 3,50

97. Boom, B. K. Benaming, geschiedenis en kenmerken yan een aancal houtachtige planten. Nomenclature, history and characteristics of some woody plants. Maart 1957 ................... . . f 2,50

\section{PERSBERICHTEN UITSLAGEN PRACTJJKRROEVEN}

11- 3-'51. Uitslag Practijkproeven Westlandse Boerenkool 1949-1950.

3- 9-'51. Uitslag Practijkproeven Spitskool 1950-1951.

23- 1-'52. Uitslag Practijkproeven Vroege en Herfst Rodekool 1950-1951.

31- 3-'52. Uitslag Practijkproeven Spruitkool 1950-1951.

4-11-'52. Uitslag Practijkproeven Ronde Rode Radijs 1951-1952.

4-11-'52. Uitslag Practijkproeven Vroege Rijspeulen 1951-t952.

25-11-'52. Uitslag Practijkproeven Lange Kroten 1951-1952.

23- 1-'53. Uitslag Practijkproeven Radijs Ronde Scharlakentode Extra Kortloof 1951-1952.

13- 5-'53. Uitslag Practijkproeven Bewaar Rode Kool 1951-1952.

10- 9-'53. Uitslag Practijkproeven Vroege Witte Kool 1952-1953.

18-12-'53. Uitslag Practijkproeven Herfst Witte Kool 1952-1953.

3- 6-'54. Uitslag Practijkproeven Bewaar Witte Kool 1952-1953.

17-11-'54. Uitslag Practijkproeven Stoksnijbonen 1953-1954

2-12-'54. Uitslag Practijkproeven Ronde Rode Witpunt Radijs 1953-1954.

12- 2-'55. Uitslag Practijkproeven Knolselderij 1953-1954.

1. 9-'55. Uitslag Practijkproeven Vroege Groene Savoye Kool 1954-1955.

14-11-'55. Uitslag Practijkproeven Tomaten 1954-1955.

27 12.'55. Uitslag Practijkproeven Witlof vroege trek 1954-1955.

2-3-'56. Uitslag Practijkproeven Witlol middelyroege trek 1954-1955.

5-3.'56. Uitslag Practijkproeven Schorseneren 1954-1955.

28- 5-'56. Uitslag Practijkproeven Savoye Kool 1954-1955.

28- 5-'56. Uitslag Practijkproeven Witlof koude kuil en meilof 1954-1955.

30- 7-'56. Uitslag Practijkproeven Tuinbonen 1955-1956.

1. 9-'56. Uitslag Praktijkproeven Amsterdamse Bakwortel 1955-1956

1. 9-'56. Uitslag Praktijkproeven Vroege Rode Kool 1956

1. 9-56. Uitslag Praktijkproeven Platronde Kroten 1955-1956

20- 9-'56. Uitslag Praktijkprooven Pronkbonen 1955-1956.

26-11-'56. Uitslag Praktijkproeven Herfstprei 1955.1956.

31-1-'57. Uitslag Praktijkproeven Winterwortelen 1955-1956.

Zijn geplaatst in diverse tuinbouwbladen 


\section{RASSENLIJSTEN ${ }^{1}$ ) \\ UITGEGEVEN DOOR HET INSTITUUT VOOR DE VEREDELING VAN TUINBOUWGEWASSEN}

Achtste Beschrijvende Rassenijist yoor Fruit. 1957. . f 1,75 Negende Beschrijvende Rassenlijst voor Groentegewassen, 1957. Redacteur Dr. O. Banga ..... f 1,75

\section{PUBLIKATIES VAN HET INSTITUUT VOOR DE VEREDELING VAN TUINBOUWGEWASSEN IN ANDERE ORGANEN OF IN BOEKVORM EVENTUEEL IN SAMENWERKING MET ANDERE INSTELLINGEN ${ }^{2}$ )}

De publikaties, waarvan prijs èn uitgever worden vermeld zijn verkrijgbaar in de boekhandel. Overigens wende men zich cot de opgegeven bronnen of tot de bibliotheek van het I.V.T.

Boom, B. K. Cotoneaster wardii en verwante soorten. De Boomkwekerij 11, $1955: 3$.

Gerritsen, C. J. Zit er wat in de teelt van hazelnoten? De Fruitceelt 45, 1955: 865 .

Kronenberg, H. G. Aardbeien. Wat moeten we toch planten? De Fruitteelt 45, 1955: 866-867.

Gerritsen, C. J. Gaat $U$ kersen planten? De Fruitteelt 45 1955: 909-910.

Burg, J. P. L. L. A. en G. Elzenga. Rapport over een studiereis aangaande de teelt en verwerking van geneeskrachtige en aromatische gewassen in Duitsland en Frankrijk $(16 \mathrm{t} / \mathrm{m}$ 31 augustus 1955). V.N.K.-Nieuws, september 1955: 92-99.

Boom, B. K. Sorbus pratti en S. koeneana. De Boomkwekerij 11, 1955: 27

Elzenga G. Het rooien van de wortels van Angelica en Valeriaan. V.N.K.-Nieuws, november 1955: 110-111

Elzenga, G. Pepermunt opnieuw inplanten. V.N.K.-Nieuws, november 1955: 112.

Boom, B. K. Vrazgstukken rondom het Cotoneaster-sortiment. De Boomkwekerij t1, 1955, 41-42.

Jensma, J. R. Rassenkeuze bij bloemkool. Groenten en Fruit 11, $1956: 721$.

Bruyne, A. S. de. Nieuwe appelrassen tot James Grieve. De Fruitwereld 1, 1956; no 4; 8-9.

Boom, B. K. Cercidiphyllum. De Boomkwekerif 11, 1955: 27

Broertjes, C. Reactie op vraagstukken rondom het Cotoneastersortiment. De Boomkwekerij 11, 1956: 67-68.

Broertjes, C. Veredeling op ziekteresistentie bij rozen. De Boomkwekerij 11, 1956: 73 .

Boom, B. K. Acer platanoides, reikenbach' en rubrum' De Boomkwekerij 11, 1956: 74

Bruyn, J.W. de. De exportcontrole van kruiden in 1955. V.N.K.-Nieuws, januari 1956: 134-135.

Boom, B. K. Buxus, buksus of buks. De Boomkwekerij 11 1956: $80-81$

Boom, B. K. Drie nieuwe wilgen. De Boomkwekerij 11, 1956: $81-82$.

Boom, B. K. Enkele bontbladige bomen. De Boomkwekerij 11, $1956: 88$

Boom, B. K. Een nieuwe monographie over het geslacht Philadelphus. De Boomkwekerij 11, 1956: 96-97.

Gerritsen, C. 1. Zal de noot een deugd worden? De Fruitwereld 1,$1956 ;$ no. 14: 5 .

Banga, 0 . Enkele opmerkingen naar aanleiding van een inter nationale conferentie. Zaadbelangen 10, 1956: 101-102.

Kronenberg, H. G. Strawberry growing in the Netherlands. American Fruit Grower 76, 1956; no. 4: 77

Elzenga, G. Lobelia inflata. V.N.K.-Nieuws, maart 1956: 163 166.

Boom, B. K, Variëteit en cultivar. De Boomkwekerij 11, 1956: 112-113.

Andeweg, 1, M. Vroegrijpende moneymaker's. Zaadbelangen $10,1956: 145$

Boom, B. K. Verwarring over de plantennamen. Vakolad voor de Bloemisterij 11, 1956: 130-131.

Gijsbers, J. W. Ruimtebesparing bij de opberging van dia's en negatieven. Meded. Dir. Tuinbouw 19, 1956: 298-300

Boom, B. K. Over een verzameling prijscouranten. De Boomkwekerij 11, 1956: 128-129.

Boom, 8. K. Een Amerikaan over Boskoop. De Boomkwekerij 11, 1956: 130.
Huyskes, J. A. Klauwenselectíe bij asperges geeft goede resultaten. Boer en Tuinder (Land en Vee) 10, 1956: no. $482 ; 17$.

Koot, $Y$, v. en J. M. Andeweg. De groenteteelt in Amerika. 's-Gravenhage, C.O.P., 1956. 149 blz. $f$ 7,00

Banga, $\boldsymbol{Q}$. Kweker en overheid in de sector groentezaden. Zaadbelangen 10, 1956: 189-190.

Kho, Y, O. Opbrengstvermindering en kiemkrachtverlaging van wortelzaad als gevolg van aantasting door wantsen. Zaadbelangen 10, 1956: 193-194.

Elzenga, G. Digitalis lanata Ehr. V.N.K.-Nieuws 1956 $167-170,193-199$.

Andeweg, J. M. Rationalisatie en rassenkeuze. Groenten en Fruit 12, 1956: 111.

Kho, Y. O. en J. P. Braak. Opbrengstvermindering en kiemkracheverlaging van wortelzaad als geyolg van aantasting door wantsen. Meded. Dir. Tuinb. 19, 1956: 440-445.

Kronenberg, H. G. Praktijkproeven met aardbeien in 1956 De Tuinderij 36, 1956, no 33: 1-3. Groenten en Fruit 12 1956: 177

Floor, J. en P. A. Wezelenburg. Scekken onder plastic. De Boomkwekerij, 11, 1956: 174-175.

Terpstra, W. Some factors influencing the abscission of debladed leaf petioles. Acta Botanica Neerlandica 5, 1956: 157-170

Bruyne, A. S. de. Trends and developments in Dutch varieties. The Commercial Grower 1956, no 3165: 419-422.

meets, L. A note on the shortening of the juvenile phase in cherry seedlings. Euphycica 5, 1956: 117-118.

Boertjes, C. Vorstschade aan Rhododendronvariëteiten in in 1956. De Boomkwekerij 11, 1956: 187-189.

Rodenburg, C. M. Het kweken van wolfresistente spinazierassen. Zaadbelangen 10, 1956: 325-326.

Andeweg, J. M. Een wardevolle vroege kruisingsouder. Zaadbelangen 10, 1956: 344.

Huyskes, J. A. en C. M. Rodenburg. Internationale samenwerking bij hec onderzoek van slarassen. Meded. Dir. Tuinb. 19, 1956: 823:826.

Gerritsen, C. J. De teelt van buitenperziken I, II. III, IV. Groenten en Fruit 12, 1956: 537-538; 569-570; 603; 628-629.

Gerritsen, C. J. De Feyoa, aan nieuw cultuurgewas? Meded. Dir. Tuinb. 19, 1956: 889.894.

Jensma, J. R. Sluickoolrassen. Wageningen, I.V.T. 1956: 150 blz. $\{13.50$

Floor, J. Planten in plastic. Wageningen, f.V.T., 1956. 0.35

Elzenga, G. De teelt van Valeriaan. V.N.K.-Nieuws 4 1956: 234-236.

Elzenga, G. Het mechanisch rooien van Valeriaan. V.N.K.Nieuws 4, 1956: 246.

Elzenga, $\mathbf{G}$. Het opkweken van plantmateriaal van Levisticum en Rheum. V.N.K.-Nieuws 4, 1956: 246-247.

Elzenga, G. Roest in mune. Zou gier helpen? V.N.K.Nieuws 4, 1956: 247.

Elzenga, $\boldsymbol{G}$. Mechanisch planten van Valeriaan blijkt zeer goed mogetijk. V.N.K.-Nieuws 4, 1956: 248-249.

Elzenga, G. De oogstdatum van Digitalis lanata. V.N.K. Nieuws 4, 1956: 249-250.

Giessen, A. C. v. d. en A. v. Steenbergen. Een nieuwe methode voor de toetsing yan bonen op resistentie tegen vlekziekte. Zaadbelangen 11, 1957: 26-27.

1) Zolang de voorraad strekt kunnen deze publikaties franco worden toegezonden, na ontvangsc van het vermelde bedrag op giro no. 425340 van het Instituut voor de Veredeling van Tuinbouwgewassen, S. L. Mansholtiaan 15 te Wageningen onder vermelding van wat verlangd wordt; ook bestaat de mogelijkheid deze publikaties uit de bibliotheek van het I.V.T. te lenen.

2) Eerder verschenen publikaties zijn vermeld achterin in de Mededelingen nos $1 \mathrm{t} / \mathrm{m} 89$. 